\title{
واقع الأداء الرقابى بالأندية الرياضية بدولة الكويت
}

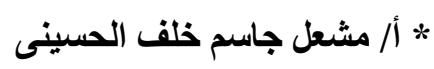

هقدمهة وهشكلة البحث

إن للإدارة أهمية بالغة بالنسبة لكل فرد ولكل مجموعة من الأفراد يمارسون أى نثاط فى أى مجتمع من المجتمعات وذلك لأنها تعمل كعنصر معاون على تحقيق الأهداف التى يسعى إليها الأفراد ، وتعنى الإدارة بذلك حسن إستخدام قدرات الأفراد ومعلوماتهم والإمكانات والموارد المتاحة بما يحقق الأهداف المرغوب الوصول إليها بأفضل الأساليب وأقل الجهد والتكاليف وبأفضل عائد

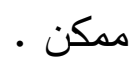

تتميز العملية الإدارية بإعتمادها على العنصر البشرى فى كافة مراحلها ، ولما كان الأداء

البشرى متغيرا بطبيعته , إذ أنه من الصعب التحكم فيه وإخضاعه لنمط معين بدرجة مائة بالمائة .

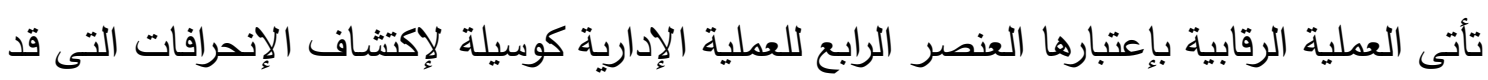
تحدث أثناء عملية التنفيذ وحل المشكلات التى قد تعترض بلوغ الأهداف .

$(241: 12)$

والرقابة داخل الأندية الرياضية هى تلك العملية التى يتم من خلالها متابعة تتفيذ الأعمال وقياس الأداء وفقا للمعايير الرقابية المحددة التى تعمل على قياس مدى ما يتحقق من الأهداف الموضوعة والمراد إنجازها ، والرقابة تعمل أيضا على الكثف عن السلبيات لتداركها وتوجيه إنحرافها نحو مسارها المحدد ومعالجتها ، وذلك بهدف الوصول بالإدارة إلى أعلى أداء ممكن . $(268: 10)$

ولما كانت الأندية الرياضية من المؤسسات التربوية التى تلعب دورا هاما ومؤثر فى توجيه

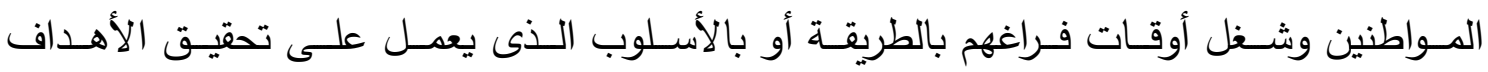
المنشودة.(11 : 58 ، 57 (1)

ولقد لاحظ الباحث من خلال وجوده كلاعب كرة طائرة بنادى الجهراء الرياضى ومن خلال وجـوده كمدرب بالنـادى والمنتخب وكعضـو عامـل بنـادى الجهراء الرياضـى إلى إفتقار الأنديـة الرياضية للأسلوب الرقابى الأمثل الذى يتم من خلاله معالجة مستمرة للأسباب الحقيقية * مدير مدرسة على سالم الصباح المتوسطة بمنطقة الجهراء التعليمية. 
للمشكلات مـع منع حدوثها بما يحقق الأهداف المنشودة التى نشأت من أجلها ، كما لاحظ أن مفهوم الرقابة ينحصر فى الرقابة على الشئون المالية والحسابية ، وهذا يضيق النظرة إلى الرقابة

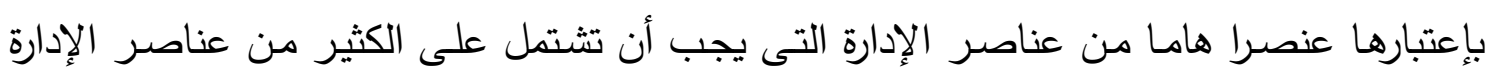

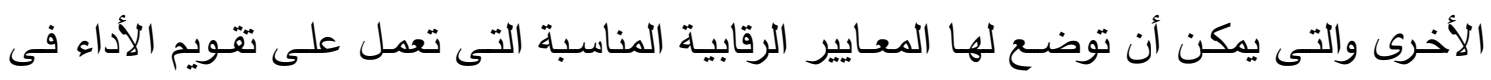
المؤسسات او الهيئات او الأندية الرياضية ، ومن ثم فان فاعلية الرقابة فى المؤسسات أو الأندية

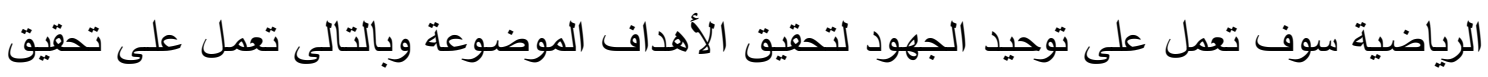

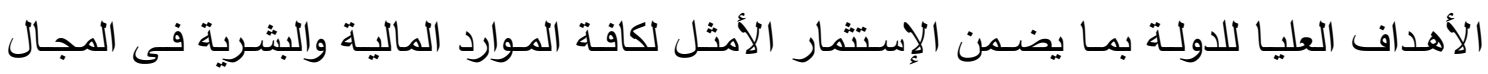
الرياضى بثكل خاص ، ومن منطلق أن الرقابة على الأندية الرياضية هى الوسيلة الوحيدة للتحقق

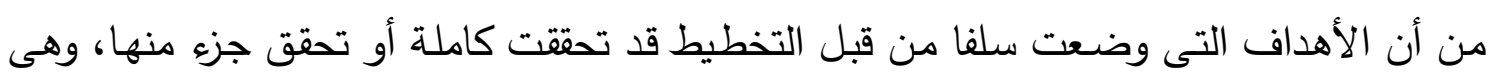
بالتالى تعمل على تلافى هذه المواطن بوضع الحلول للمشاكل التى أظهرتها الرقابة وأوضحت بأنها

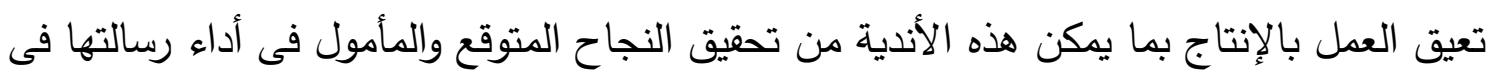
إطار العمل المخطط المستتد إلى إستراتيجية قائمسة على الموضوعية فى أفكارها ، وأن أى تدهور يلحق بالأندية الرياضية ولو بسيط فإنه يؤثر على المستوى الفنى للعبات الرياضية بدولة الكويت وكذلك يؤثر على قوة وصـلاحية إتحادات اللعبات الرياضية ، ويعتبر تعدد الأدوار التى يقوم بها النادى الرياضى داخل المجتمع الكويتى بصفة عامة وداخل المجتمع الرياضى بصفة خاصـة هيى

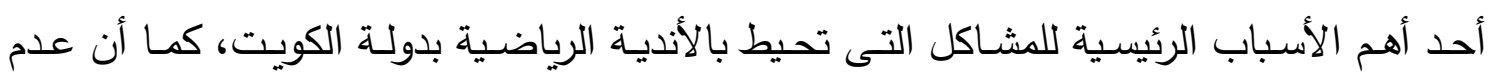
إخضـاعها لرقابة جادة ومستمرة تحكم سير العمل بها من المشكلات الرئيسية التى تحول دون تحقيق المستويات والإنجازات المتوقعة فى البطولات الدولية والعالمية ،ومن هذا المنطلق كان تفكير الباحث فى دراسة واقع الأداء الرقابى بالأندية الرياضية بدولة الكويت.

تعد الرقابـة على الأنديـة الرياضية بدولـة الكويت من أهم الموضـوعات التى تهم الميدان الرياضـى لما لهذا الموضوع من أهمية كبيرة فى تتظيم العمل ، لذلك يحاول الباحث من خـلال البحث الحالى تقويم النظام الرقابى الخاص بالاندية الرياضية والتعرف على أساليب الرقابة فى هذه الأندية إن وجدت وإيجاد أسلوب فعال من أساليب الرقابة يطبق على المؤسسات الرياضية لمحاولة 
توحيد جهودها فى إتجاه تحديد الأهداف المطلوبة سواء كانت أهداف قصيرة المدى (تكتيكية) أو

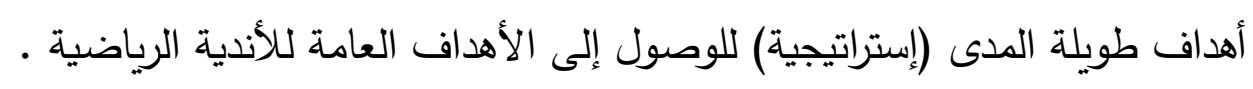

يهدف البحث الى التعرف على واقع الأداء الرقابى بالأندية الرياضية بدولة الكويت وذلك من

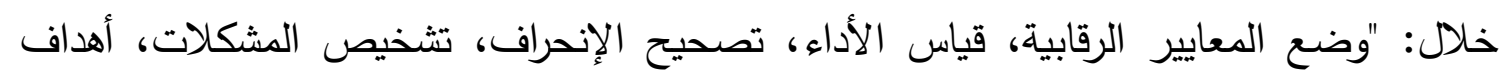
الرقابة" بالأندية الرياضية بدولة الكويت.

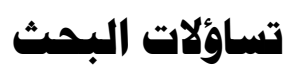

ما واقع الأداء الرقابى بالأندية الرياضية بدولة الكويت وذلك من خلال : "وضع المعايير الرقابية، قياس الأداء، تصحيح الإنحراف، تشخيص المشكلات، أهداف الرقابة" بالأندية الرياضية بدولة الكويت.

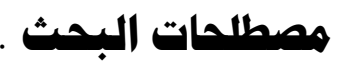

Administrative Control . الرقابة الإدارية " هى ذلك النوع من الرقابة الذى يمارس على كل هيئة أو منظمة على أوجه النشاط والمهام التى تؤديها ، فهى تمتد لجميع العمليات التى تؤديها الوحدات التظظيمية طبقا للوائح والتخطيط الموضوع لها". (6) : (111) (1)

إجراءات البحث

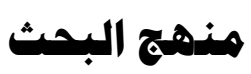

إستخدم الباحث فى دراسته المنهج الوصفى بالأسلوب المسحي لمناسبته لطبيعة هذا البحث.
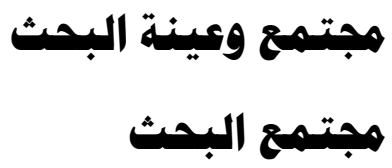

قام الباحث بإختيار مجتـع البحث ويمثله روؤسـاء وأعضـاء مجالس الإدارات ، المديرين التتفيذيين ، مديروا النشاط ، المديرين المـاليين ، مراقبى الحسابات ، الإداريين ، أعضـاء اللجان المختلفة ، أعضاء الجمعية العمومية " بالأندية الرياضية بدولة الكويت، وأعضاء إدارات (التفتيش ،رئي 
المـالى والإدارى ، العامة للرياضـة ، الثئون القانونيـة ، الهيئات) بالهيئة العامة للشباب والرياضـة بدولة الكويت.

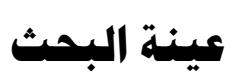

تم اختيار عينة البحث بطريقة عشوائية من مجتمع البحث من روؤساء وأعضاء مجالس الإدارات ، المديرين التتفيذيين ، مديروا النشاط ، المديرين الماليين ، مراقبى الحسابات ، الإداريين ، أعضاء اللجان المختلفة ، أعضاء الجمعية العمومية " بالأندية الرياضية بدولة الكويت، وأعضاء إدارات (التفتيش المالى والإدارى ، العامة للرياضة ، الثئون القانونية ، الهيئات) بالهيئة العامة للثباب والرياضة بدولة الكويت.، وقد بلغ عدد عينة البحث الكلية عدد 124 فرد ، حيث بلغ عدد عينة البحث الاستطلاعية عدد 20 فرد ، وبلغ عدد عينة البحث الأساسية عدد 104 فرد ، ويوضح جدول (1) تصنيف عينة البحث الاساسية والاستطلاعية .

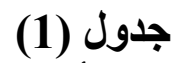

تصنيف عينة البحث الأساسية والإستطلاعية

\begin{tabular}{|c|c|c|c|c|c|c|c|c|c|c|c|c|}
\hline \multirow[b]{2}{*}{ 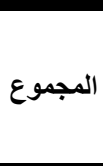 } & \multicolumn{4}{|c|}{ الهيئة العامة للشباب و الرياضة } & \multirow[b]{2}{*}{ الإداريين } & \multirow[b]{2}{*}{ العموميةية } & \multirow[b]{2}{*}{ الومراقياتييني } & \multirow[b]{2}{*}{ المضاء } & \multirow[b]{2}{*}{ مديريا } & \multirow[b]{2}{*}{ تنفيذيينين } & \multirow[b]{2}{*}{ وألأسضاء } & \multirow[b]{2}{*}{ العينة } \\
\hline & الهينارت & القانشئونة & للرالعاضة & والثالثنتيش & & & & & & & & \\
\hline 20 & 2 & 1 & 2 & 1 & 2 & 3 & 2 & 1 & 2 & 3 & 1 & إستطالةية \\
\hline 104 & 4 & 3 & 4 & 3 & 14 & 34 & 5 & 8 & 6 & 4 & 19 & أساسية \\
\hline 124 & 6 & 4 & 6 & 4 & 16 & 37 & 7 & 9 & 8 & 7 & 20 & الكجموع الكمي \\
\hline
\end{tabular}

أدوات جمهع البيانات

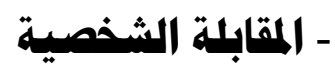

- إستبيان واقع الاداء الرقابى على الأندية الرياضية بدولة الكويت . إعداد : الباحث

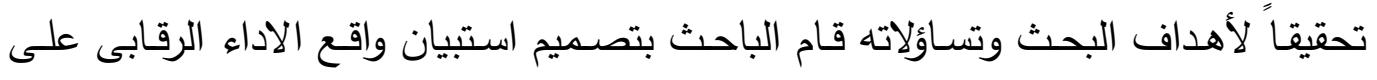
الأندية الرياضية بدولة الكويت ، ويتكون الاستبيان من عدد 82 عبارة بهدف الوقوف على واقع الأداء الرقابى على الأندية الرياضية بدولة الكويت ، وقد مر تصميم الإستبيان بالخطوات التالية: خطوات بناء الإستبيان اولا : تهديد محاور الإستبيان

قام الباحث بتحديد ستة محاور لإستبيان واقع الأداء الرقابى على الأندية الرياضية بدولة 
الكويت ، وقد توصل إليها الباحث بعد إجراء المسح المرجعى لعديد من المراجع والدراسات ذات الصلة بمجال الإدارة الرياضية

قام الباحث بعرض تلك المحاور ( مرفق 2 ) على عدد ( 12 ) من الخبراء في مجال الإدارة الرياضية (مرفق 1) مع مراعاة ألا تقل خبرتهم في المجال عن عدد (10) عشرة أعوام ، وأن يكون حاصل علي دكتوراه الفلسفة في التربية الرياضية ، وأن يكون عضو هيئة تدريس بأحد كليات التربية الرياضية بقسم الإدارة الرياضية ، وذلك بغرض : " التعرف على مدى مناسبة الدحاور للهدف الذي وضعت من أجله . " مدى كفاية هذه المحاور للوقوف على واقع الأداء الرقابى على الأندية الرياضية بدولة الكويت. * الموافقة على وجود المحور أو عدم وجوده . مان. * الموافقة على صياغة المحور أو تعديل صياغته .

\section{جدول ( 2 ( )}

نسبة آراء الخبراء حول محاور استبيان واقع الرقابة

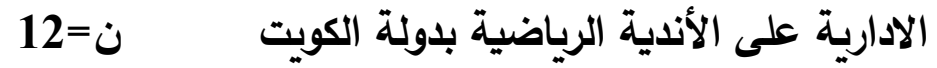

\begin{tabular}{|c|c|c|c|c|c|}
\hline ضياغرة موافحـق علـح & 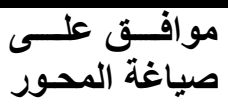 & غير موافق على المحور & موافــق عحورِى & المحــــور & s \\
\hline$\% 41.67$ & $\% 58.33$ & - & $\% 100$ & وضع المعايير الرقابية & 1 \\
\hline- & $\% 100$ & - & $\% 100$ & قياس الاداء & 2 \\
\hline- & $\% 100$ & - & $\% 100$ & تثخيص المشكلات & 3 \\
\hline- & $\% 100$ & $\% 20$ & $\% 80$ & تصحيح الانحراف & 4 \\
\hline$\% 33.33$ & $\% 66.67$ & - & $\% 100$ & اهداف العملية الرقابية & 5 \\
\hline
\end{tabular}

يوضـح جدول (2) آراء الخبراء حـول محساور استبيان واقـع الاداء الرقابى على الأنديـة

الرياضية بدولة الكويت ، حيث إرتضى الباحث بقبول المحور الذى يحقق نسبة (80\%) فأكثر من

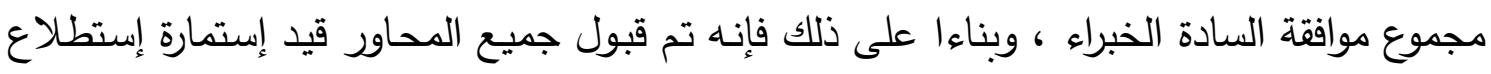

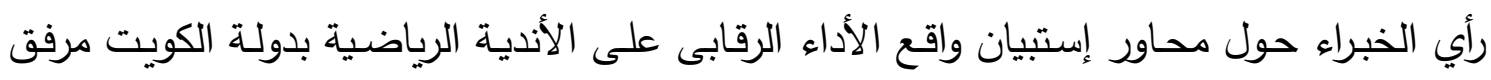

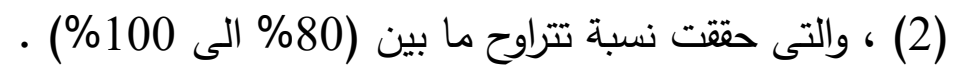

\section{ثانيا : تهديد عبارات الماور}

قام الباحث بتحديد مجموعة من العبارات الخاصة بكل محور وفقا لآراء الخبراء 
ومستندا على المراجع المتخصصة والدراسات السابقة في المجال ، وقد راعى الباحث ما يلي عند تحديد العبارات :

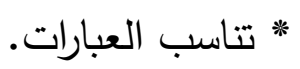

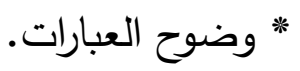

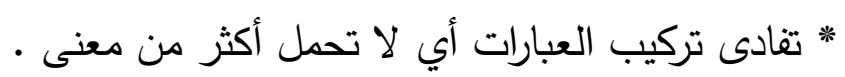
* تناسب العبارات مع الهدف الذي وضعت من أجله . وقد بلغ عدد العبارات التي تعبر عن الدحاور عدد 86 عبارة وزعت وفقا لما يلي : * المحور الأول " وضع المعايير الرقابية " ويمثله عدد 14 عبارات .

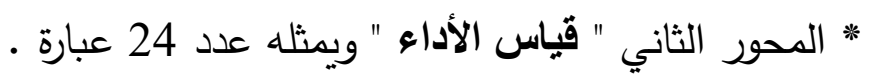
" المحور الثالث " تثخيص المشكلات " ويمثله عدد 14عبارة . * المحور الرابع " تصحيح الإنحراف " ويمثله عدد 15 عبارات . * المحور الخامس " أهداف العملية الرقابية " ويمثله عدد 19 عبارات .

\section{عرض الإستبيان في صورته المبدئية}

قام الباحث بعرض الإستبيان في صورته المبدئية (الأولية) متضمنا المحاور والعبارات التي تمثلها(مرفق 3) على الخبراء (مرفق 1) بغرض التأكد من مدى مناسبة العبارات للمحور الذي تمثله ، ومناسبة العبارة للظاهرة المقاسة ، ومدى كفاية العبارات للتعبيرعن المحور ومدى صلاحيتها للصياغة وكذا تحديد ميزان التقدير المناسب لتصحيح العبارات . وقد قام الخبراء بحذف بعض العبارات لعدم مناسبتها وكذلك التي تعتبر غير ملموسة تحتاج

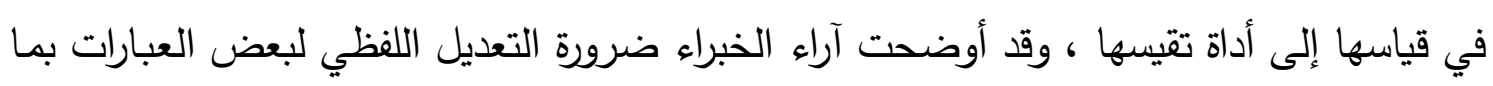
يلائم المصطلحات الثائعة في مجال الإدارة الرياضية ، وكذلك بما يناسب طبيعة الرقابة الإدارية

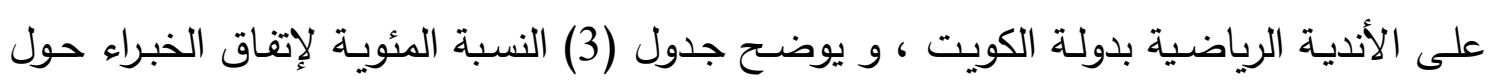

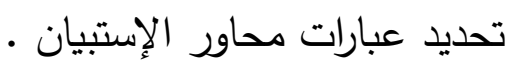




\section{جدول ( 3 )}

النسبة المئوية لإتفاق الخبراء حول تحديد عبارات محاور الإستبيان

\begin{tabular}{|c|c|c|c|c|c|c|c|c|c|}
\hline$\%$ & s & $\%$ & م & $\%$ & م & $\%$ & 5 & $\%$ & م \\
\hline \multicolumn{10}{|c|}{ المحور الأول : وضع المعايير لرقابية } \\
\hline$\% 75.00$ & 5 & $\% 58.33$ & 4 & $\% 16.67$ & 3 & $\% 91.67$ & 2 & $\% 66.67$ & 1 \\
\hline \multirow[t]{2}{*}{$\% 100$} & 10 & $\% 100$ & 9 & $\% 58.33$ & 8 & $\% 58.33$ & 7 & $\% 100$ & 6 \\
\hline & & $\% 100$ & 14 & $\% 83.33$ & 13 & $\% 91.67$ & 12 & $\% 50.00$ & 11 \\
\hline \multicolumn{10}{|c|}{ المحور الثانى : قياس الاداء } \\
\hline$\% 100$ & 19 & $\% 33.33$ & 18 & $\% 91.67$ & 17 & $\% 58.33$ & 16 & $\% 91.67$ & 15 \\
\hline$\% 91.67$ & 24 & $\% 66.67$ & 23 & $\% 100$ & 22 & $\% 100$ & 21 & $\% 91.67$ & 20 \\
\hline$\% 100$ & 29 & $\% 66.67$ & 28 & $\% 58.33$ & 27 & $\% 100$ & 26 & $\% 66.67$ & 25 \\
\hline \multirow[t]{2}{*}{$\% 66.67$} & 34 & $\% 100$ & 33 & $\% 100$ & 32 & $\% 75.00$ & 31 & $\% 91.67$ & 30 \\
\hline & & $\% 41.67$ & 38 & $\% 91.67$ & 37 & $\% 91.67$ & 36 & $\% 58.33$ & 35 \\
\hline \multicolumn{10}{|c|}{ المحور الثالث : تشخيص المشكلات } \\
\hline$\% 91.67$ & 43 & $\% 91.67$ & 42 & $\% 100$ & 41 & $\% 100$ & 40 & $\% 100$ & 39 \\
\hline \multirow[t]{2}{*}{$\% 83.33$} & 48 & $\% 100$ & 47 & $\% 58.33$ & 46 & $\% 66.67$ & 45 & $\% 91.67$ & 44 \\
\hline & & $\% 100$ & 52 & $\% 66.67$ & 51 & $\% 75.00$ & 50 & $\% 58.33$ & 49 \\
\hline \multicolumn{10}{|c|}{ المحور الرابع : تصحيح الاتحراف } \\
\hline$\% 91.67$ & 57 & $\% 100$ & 56 & $\% 66.67$ & 55 & $\% 100$ & 54 & $\% 66.67$ & 53 \\
\hline$\% 100$ & 62 & $\% 100$ & 61 & $\% 91.67$ & 60 & $\% 58.33$ & 59 & $\% 58.33$ & 58 \\
\hline$\% 75.00$ & 67 & $\% 41.67$ & 66 & $\% 91.67$ & 65 & $\% 100$ & 64 & $\% 66.67$ & 63 \\
\hline \multicolumn{10}{|c|}{ المحور الخامس : أهداف الرقابة } \\
\hline$\% 91.67$ & 72 & $\% 66.67$ & 71 & $\% 100$ & 70 & $\% 100$ & 69 & $\% 91.67$ & 68 \\
\hline$\% 75.00$ & 77 & $\% 91.67$ & 76 & $\% 58.33$ & 75 & $\% 100$ & 74 & $\% 58.33$ & 73 \\
\hline \multirow[t]{2}{*}{$\% 100$} & 82 & $\% 58.33$ & 81 & $\% 91.67$ & 80 & $\% 91.67$ & 79 & $\% 66.67$ & 78 \\
\hline & & $\% 66.67$ & 86 & $\% 91.67$ & 85 & $\% 75.00$ & 84 & $\% 100$ & 83 \\
\hline
\end{tabular}

يوضح جدول (3) النسبة المئويـة لاتفاق الخبراء حول تحديد عبارات محاور الإستبيان ،

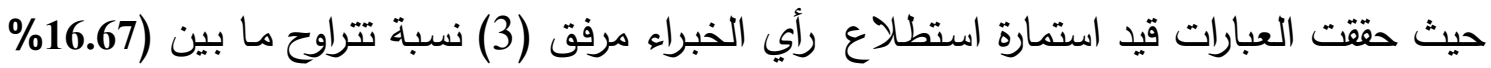

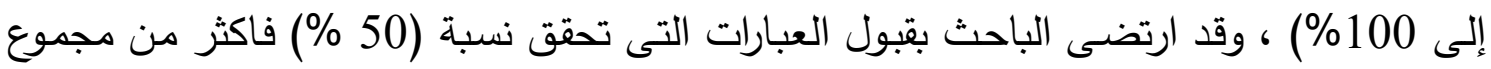
موافقة السادة الخبراء ، والجدول (4) يوضـح عدد العبارات التي تم حذفها كذلك أرقام العبارات

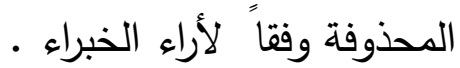

\section{جدول ( 4 ) - (}

عدد العبارات التي تم حذفها وأرقامها وفقاً لآراء الخبراء

\begin{tabular}{|c|c|c|}
\hline أرقـام العبارات المحـــوفة & عدد العبارات التي تم حذفها & المحسـور \\
\hline 3 & 1 & وضع المعاييز الرقابية \\
\hline $38 / 18$ & 2 & قياس الاداء \\
\hline- & - & تثخيص المشكلات \\
\hline 66 & 1 & تصحيح الاتحراف \\
\hline- & - & اهداف العملية الرقابية \\
\hline
\end{tabular}


يوضح جدول (4) عدد العبارات التي تم حذفها من كل محور من محاور الإستبيان ،

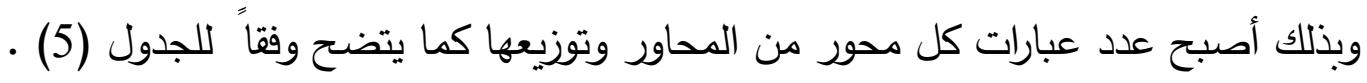

$$
\text { جدول ( } 5 \text { ) }
$$

محاور إستبيان واقع الأداء الرقابى على الأندية الرياضية

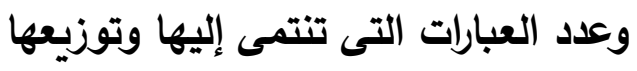

\begin{tabular}{|c|c|c|c|}
\hline عـدد العبارات & توزيع أرقام العبارات & المحـــــاور & p \\
\hline 13 & \begin{tabular}{c|}
$13-1$ \\
\end{tabular} & وضع المعايير الرقابية & $\overline{1}$ \\
\hline 22 & $35-14$ & قياس الأداء & 2 \\
\hline 14 & $49-36$ & تثخيص المشكلات & 3 \\
\hline 14 & $63-50$ & تصحيح الإنحراف & 4 \\
\hline 19 & $82-64$ & أهداف العملية الرقابية & 5 \\
\hline 82 & & 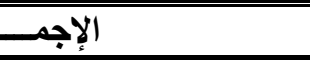 & \\
\hline
\end{tabular}

يوضح جدول ( 5 ) محاور إستبيان واقع الأداء الرقابى على الأندية الرياضية بدولة الكويت

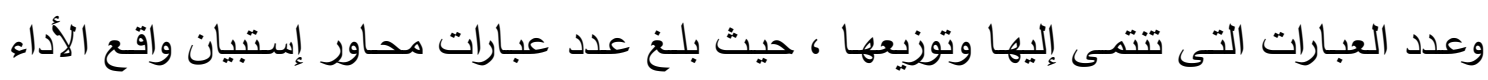

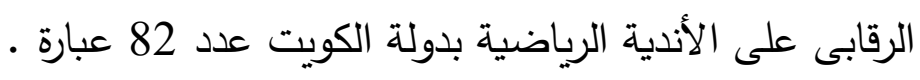

\section{الدراسة الإستطلاعية}

قام الباحث بتطبيق استبيان واقع الاداء الرقابى على الأندية الرياضية بدولة الكويت على عينة استطلاعية وقوامها عدد 20 فرد تم اختيارهم بطريقة عشوائية من عينة البحث الكلية ومن خارج العينة الاساسية، كما يتضـح بجدول ( 1 ) تصنيف عينة البحث الاساسية والاستطلاعية ، وذلك في الفترة ما بين 2020/9/21 2020/9/27 إلى وذلك بهدف ما يلي: * وضوح صياغة العبارات الخاصة، وحساب المعاملات العلمية (الصدق - الثبات) باستبيان واقع

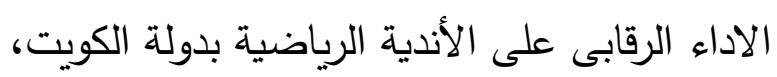

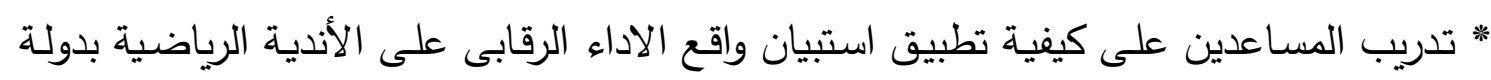
الكويت وتفريغ النتائج، تحديد ما تستغرقه الدراسة الميدانية من وقت .

المعاهلات العلمية

\section{الصدق لاستبيان واقع الأداء الرقابى على الأندية الرياضية بدولة الكويت}

صدق الاتساق الااخلي لاستبيان واقع الاداء الرقابى على الأندية الرياضية بدولة الكويت .

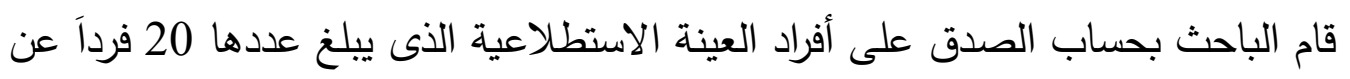


طريق صدق الاتساق الداخلى، وذلك بحساب قيمة معامل الارتباط بين درجة كل عبارة على حدة بكل بعد والدرجة الكلية لهذا البعد مع الاستبيان ككل، كما هو موضح بالجدولين (6 ، 7) .

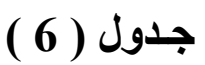

صداق الاتساق الداخلي بين درجـة كل عبارة

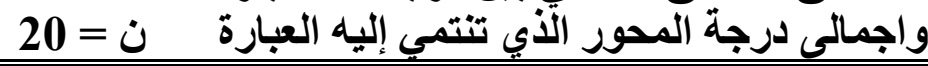

\begin{tabular}{|c|c|c|c|c|c|c|c|c|c|}
\hline معامل & P & الارتباط & c & الارتباط & e & معامل & r & مالارتباط & 5 \\
\hline \multicolumn{10}{|c|}{ المحور الأول: وضع المعايير الرقابية } \\
\hline$* 0.689$ & 5 & $* 0.511$ & 4 & $* 0.623$ & 3 & $* 0.507$ & 2 & $* 0.589$ & 1 \\
\hline$* 0.735$ & 10 & $* 0.490$ & 9 & $* 0.619$ & 8 & $* 0.580$ & 7 & $* 0.552$ & 6 \\
\hline & & & & $* 0.454$ & 13 & $* 0.548$ & 12 & $* 0.643$ & 11 \\
\hline \multicolumn{10}{|c|}{ المحور الثانى: قياس الأداء } \\
\hline$* 0.562$ & 18 & $* 0.539$ & 17 & $* 0.463$ & 16 & $* 0.567$ & 15 & $* 0.546$ & 14 \\
\hline$* 0.554$ & 23 & $* 0.490$ & 22 & $* 0.534$ & 21 & $* 0.629$ & 20 & $* 0.490$ & 19 \\
\hline$* 0.648$ & 28 & $* 0.503$ & 27 & $* 0.506$ & 26 & $* 0.684$ & 25 & $* 0.558$ & 24 \\
\hline$* 0.620$ & 33 & $* 0.567$ & 32 & $* 0620$ & 31 & $* 0.503$ & 30 & $* 0.648$ & 29 \\
\hline & & & & & & $* 0.459$ & 35 & $* 0.556$ & 34 \\
\hline \multicolumn{10}{|c|}{ المحور الثالث: تثخيص المشكلات } \\
\hline$* 0.603$ & 40 & $* 0.582$ & 39 & $* 0.792$ & 38 & $* 0.549$ & 37 & $* 0.636$ & 36 \\
\hline$* 0.626$ & 45 & $* 0.656$ & 44 & $* 0.692$ & 43 & $* 0.693$ & 42 & $* 0.697$ & 41 \\
\hline & & $* 0.616$ & 49 & $* 0.560$ & 48 & $* 0.480$ & 47 & $* 0.579$ & 46 \\
\hline \multicolumn{10}{|c|}{ الدحور الرابع: تصحيح الانحراف } \\
\hline$* 0.761$ & 54 & $* 0.645$ & 53 & $* 0.622$ & 52 & $* 0.587$ & 51 & $* 0.574$ & 50 \\
\hline$* 0.630$ & 59 & $* 0.475$ & 58 & $* 0.707$ & 57 & $* 0.715$ & 56 & $* 0.691$ & 55 \\
\hline & & $* 0.508$ & 63 & $* 0.626$ & 62 & $* 0.567$ & 61 & $* 0.582$ & 60 \\
\hline \multicolumn{10}{|c|}{ المحور الخامس: أهداف الرقابة } \\
\hline$* 0.454$ & 68 & $* 0.711$ & 67 & $* 0.636$ & 66 & $* 0.473$ & 65 & $* 0.578$ & 64 \\
\hline$* 0.591$ & 73 & $* 0.459$ & 72 & $* 0.559$ & 71 & $* 0.517$ & 70 & $* 0.468$ & 69 \\
\hline \multirow[t]{2}{*}{$* 0.739$} & 78 & $* 0.611$ & 77 & $* 0.525$ & 76 & $* 0.533$ & 75 & $* 0.706$ & 74 \\
\hline & & $* 0.468$ & 82 & $* 0.714$ & 81 & $* 0.602$ & 80 & $* 0.524$ & 79 \\
\hline
\end{tabular}

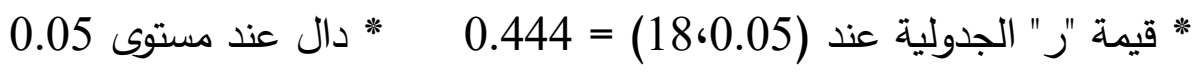
يوضح جدول ( رقم 6 ) وجود علاقة ارتباطيه دالة إحصائيا بين درجة كل عبارة والمحور الذى تتنمى إليه العبارة ، كما يتضح أن قيم معاملات الارتباط جميعها تفوق حد الدالالة الإحصائية عند مستوى 0.05 وهذا يكون مؤشرا لصدق البناء الداخلى للاستبيان. 


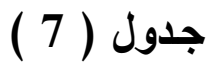

معامل الارتباط بين المحاور والارجة الكلية للاستبيان

\begin{tabular}{|c|c|c|}
\hline معامل الارتباط & المحـاور & م \\
\hline$* 0.894$ & وضع المعايير الرقابية & 1 \\
\hline$* 0.906$ & قياس الأداء & 2 \\
\hline${ }^{*} 0.899$ & شخخيص المشكلات & 3 \\
\hline$* 0.934$ & تصحيح الانحر اف & 4 \\
\hline$* 0.897$ & اهداف العملية الرقابية & 5 \\
\hline
\end{tabular}

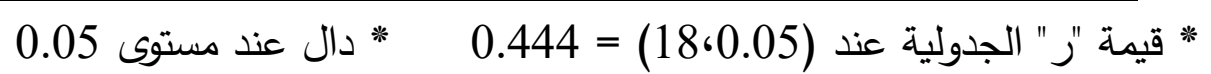

يوضح جدول ( رقم 7 ) وجود علاقة ارتباطيه دالة إحصائيا بين درجة كل محور والدرجة

الكليـة لاستبيان واقع الاداء الرقابى على الأنديـة الرياضـية بدولــة الكويت ، كمـا يتضـح أن قيم

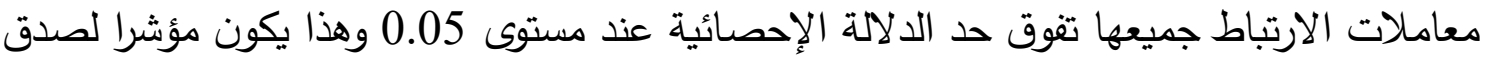

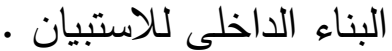

\section{الثبات لاستبيان واقع الاداء الرقابى على الأندية الرياضية بدولة الكويت}

تم حساب معامل ثبات الاستبيان على أفراد العينة الاستطلاعية السابقة خلال الفترة من

، Coefficient Alpha 2020/9/21 إلى 2020/9/27م وذلك بتطبيق معامل ألفا كرونباخ ثم قام الباحث بإجراء الثبات للاستبيان على نفس عينة الدراسة الاستطلاعية السابقة باستخدام طريقة تطبيق الاختبار ثم إعادة تطبيقه Test - Retest تحت نفس شروط التطبيق الأول ، وتم حساب معامل الارتباط بين التطبيقين، كما هو موضح فى ( جدول 8 ).

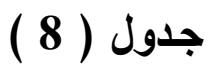
معامل الثبات لاستمارة الاستبيان باستخدام طريقة تطبيق

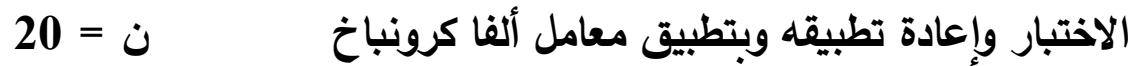

\begin{tabular}{|c|c|c|c|c|c|c|c|c|}
\hline \multirow{2}{*}{ ألفا كرونباخ الثبات } & \multirow{2}{*}{ الارتباط معامل } & \multirow[b]{2}{*}{ التطبيقين بين } & \multicolumn{2}{|c|}{ التطبيق الثانى } & \multicolumn{2}{|c|}{ التطبيق الأول } & \multirow[b]{2}{*}{ المحساور } & \multirow[b]{2}{*}{ r } \\
\hline & & & الالاعراف & الحستوسط & الالحعراف & الحستوسط & & \\
\hline$* 0.495$ & $* 0.889$ & 0.85 & 3.978 & 30.40 & 3.817 & 29.55 & وضع المعايير الرقابية & $\overline{1}$ \\
\hline$* 0.506$ & $* 0.972$ & 0.65 & 5.669 & 49.40 & 5.928 & 48.75 & قياس الأداء & 2 \\
\hline$* 0.569$ & $* 0.941$ & 1.00 & 4.155 & 31.00 & 4.507 & 30.00 & تشخيص المشكلات & 3 \\
\hline$* 0.484$ & $* 0.963$ & 1.05 & 3.694 & 32.20 & 4.428 & 31.15 & تصحيح الانحراف & 4 \\
\hline$* 0.619$ & $* 0.978$ & 0.60 & 4.996 & 42.30 & 4.932 & 41.70 & أهداف الرقابة & 5 \\
\hline
\end{tabular}

يوضح جدول ( رقم 8 ) معامل الارتباط بين بين التطبيقين ومعامل ألفا كرونباخ لاستبيان واقع الاداء الرقابى على الأندية الرياضية بدولة الكويت ـ حيث يتضح وجود علاقة ارتباطيه دالة 
إحصائيا بين التطبيقين لمحاور استبيان واقع الاداء الرقابى على الأندية الرياضية بدولة الكويت ،

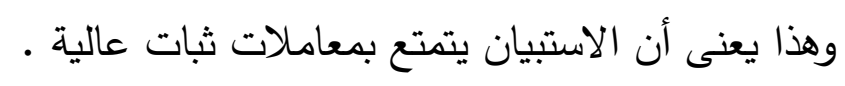

الصورة النهائية لاستبيان واقع الاداء الرقابى على الأندية الرياضية بدولة الكئية الكويت

بناءا على نتيجة إستطلاع أراء الخبراء تم الموافقة على وجود بعض العبارات تحت كل محور مـع تعديل صياغة بعض هذه العبارات وكذلك حذف البعض الآخر وبذلك اصبح عدد إنداء العبارات المكونة للاستبيان عدد 82 عبارة ، وكذلك أوضحت آراء الخبراء بضرورة أن يتم تصحيح الاستبيان وفقا لميزان تقدير ثلاثى (نعم" ، الى حد ما ، لان) .

ومن خلال نتائج الجداول رقم (8،766) والخاصة بإجراء المعاملات العلمية يكون الباحث

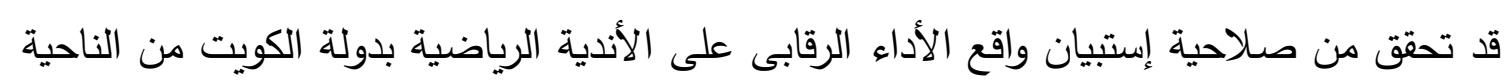

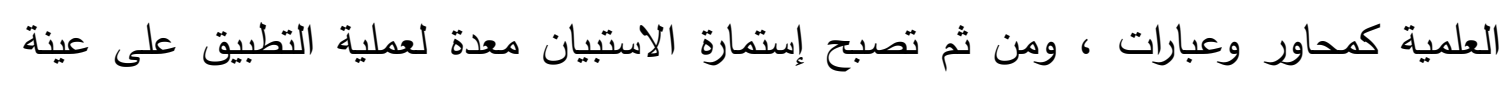
البحث الأساسية ، بحيث تمثل الدرجة الكلية لفرد عينة البحث مجموع درجات العبارات المختلفة التي يتكون منها الإستبيان .

\section{الدراسة الأساسية}

قام الباحث بتطبيق إستبيان واقع الأداء الرقابى على الأندية الرياضية بدولة الكويت مرفق

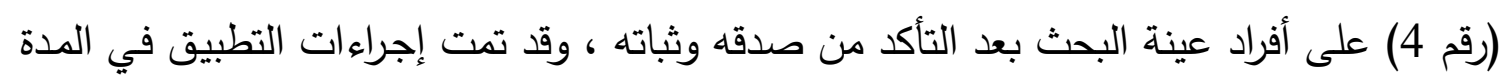
من 2020/10/17م إلى 2020/10/31م. الاسلوب الاحصائي قام الباحث بإستخدام المعالجات الإحصائية التالية عند مستوى الدلالة 0.05، وهى :

Arithmetic Mean

Standard Deviation

Coefficient of correlation

The percent

Chi-square
- المتوسط الحسابى. - الإنحراف المعيارى. - معامل الإرتباط. - النسبة المئوية. - 


\section{عرض وهناقشة النتائج}

اولا : عرض النتائج

1- عرض نتائج استجابات افراد عينة البحث لعبارات هحور وضع المعايير الرقابية

جدول (9)

التكرار والنسبة المئوية وقيمة كا² وترتيب العبارات لاستجابات افراد

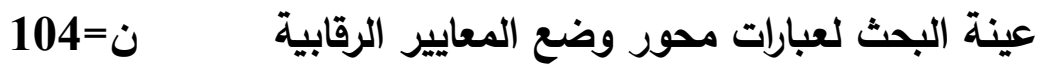

\begin{tabular}{|c|c|c|c|c|c|c|c|c|c|}
\hline \multirow{2}{*}{ الترتيب } & \multirow{2}{*}{ المحسوبة } & \multirow{2}{*}{ النسبى } & \multicolumn{2}{|c|}{$\gamma$} & \multicolumn{2}{|c|}{ الى حد مـا } & \multicolumn{2}{|c|}{ نعم } & \multirow{2}{*}{ المبارات } \\
\hline & & & نسبة \% & تكرار & نسبة ٪ & تكرار & نسبة \% & |تكرار & \\
\hline 1 & ${ }^{*} 99.26$ & $\overline{288}$ & 0.96 & 1 & 21.15 & 22 & 77.88 & 81 & 1 \\
\hline 2 & ${ }^{*} 46.46$ & 264 & 3.85 & 4 & 38.46 & 40 & 57.69 & 60 & 2 \\
\hline 3 & *36.49 & 255 & 5.77 & 6 & 43.27 & 45 & 50.96 & 53 & 3 \\
\hline 33 & ${ }^{*} 46.41$ & 255 & 1.92 & 2 & 50.96 & 53 & 47.12 & 49 & 4 \\
\hline 6 & ${ }^{*} 46.69$ & 254 & 1.92 & 2 & 51.92 & 54 & 46.15 & 48 & 5 \\
\hline 9 & *47.56 & 247 & 2.88 & 3 & 56.73 & 59 & 40.38 & 42 & 6 \\
\hline 33 & ${ }^{*} 43.41$ & 255 & 2.88 & 3 & 49.04 & 51 & 48.08 & 50 & 7 \\
\hline 13 & ${ }^{*} 32.83$ & 211 & 7.69 & 8 & 52.88 & 55 & 29.81 & 31 & 8 \\
\hline 8 & ${ }^{\star} 38.80$ & 249 & 4.81 & 5 & 50.96 & 53 & 44.23 & 46 & 9 \\
\hline 99 & ${ }^{*} 28.52$ & 247 & 8.65 & 9 & 45.19 & 47 & 46.15 & 48 & 10 \\
\hline 11 & ${ }^{*} 37.00$ & 246 & 5.77 & 6 & 51.92 & 54 & 42.31 & 44 & 11 \\
\hline 7 & ${ }^{*} 44.57$ & 251 & 2.88 & 3 & 52.88 & 55 & 44.23 & 46 & 12 \\
\hline 12 & ${ }^{*} 27.48$ & 236 & 10.58 & 11 & 51.92 & 54 & 37.50 & 39 & 13 \\
\hline
\end{tabular}

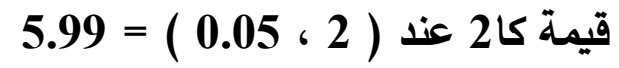

يتضـح من جدول ( 9 ) أن قيمة كا2 المحسوبة لإستجابات أفراد عينـة البحث لعبارات

محور وضع المعايير الرقابية جميعها دالة إحصائيا عند مستوى معنوية 0.05 ـ يتضح من نتائج جدول (9) أن استجابات افراد عينة البحث لعبارات محور وضع إستع المعايير

الرقابيـة قد تراوح التكرار للإجابـة ( نعم ) مـا بـين (31 ، 81) وبنسبة مئويـة تتـراوح مـا بين (29.81\% ، 77.88\%), ويتراوح التكرار للإجابة (إلى حد ما) ما بين (22 ، 59) وبنسبة مئوية تتراوح ما بين (21.15\%، 56.73\%) , ويتراوح التكرار للإجابة ( لا ) ما بين (1 ، 11) وبنسبة مئويـة تتراوح مـا بين (0.96\% ، 10.58\%), وأن قيمة كا2 الدحسوبة تتراوح ما بين (27.48 , 99.26) ، وهى فروق ذات دلالة إحصائية فى الاستجابة لجميع عبارات المحور، حيث جاءت

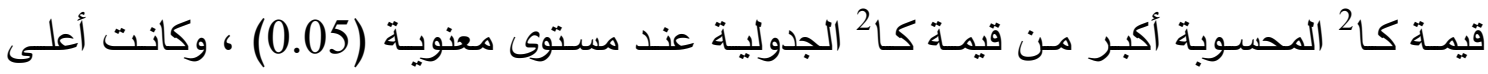


الدرجات تكراراً للإجابة ( نعم ) هى أنه توجد معايير رقابية بالأندية الرياضية بدولة الكويت ، وان

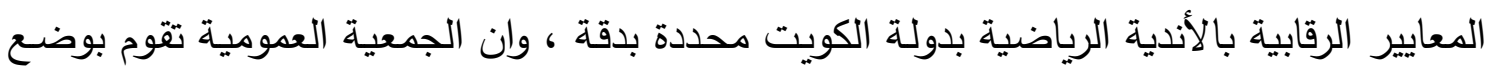
معايير رقابية لقياس اداء النادى الرياضى التابعـة لـه ، وان تطبيق المعايير الرقابية يحتاج الىى كفاءات ادارية ، وان المعايير الرقابية توضع فى ضوه الامكانات المتاحة داخل الأندية الرياضية

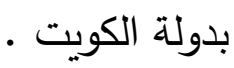

ويعزى الباحث ذلك الى ان خطط الأندية الرياضية تختلف فى درجة تفاصيلها وتعقيداتها ، ولذلك فهى تحتاج الى كثير من المعايير تتفق مع هذه التفصيلات ، وقد تم الاتفاق على معايير واضحة ومحددة تتسم بسهولة تطبيقها وسهولة فهمها وقلة تكلفتها . إن المعايير تعتبر بمثابة نقاط يتم اختيارها بتركيز معين للتدليل على انجاز البرامج او الخطة المعينة بحيث ان قياس الاداء عن طريقها تعطى دلائل محددة عن مدى دقة الاداء ، بمعنى انه يجب ان أحدد بدقة ما الذى يجب ان اقوم برقابته ـ (2 : 215) وتتقق تلك النتائج مع دراسة ثروت محمد عبد الله ابو السبح 2005م (3) فى عدم تحديد المعايير الرقابية بدقة وعدم تدوينها ، وعدم الاسترشاد بالمعايير الرقابية المستحدثة فى هيئات اخرى

وهذا يجيب عن التساؤل القائل " ما واقع الأداء الرقابى بالأندية الرياضية بدولة الكويت

وذلك من خلال وضع المعايير الرقابية بالأندية الرياضية بدولة الكويت ؟ " . 2- عرض نتائج إستجابات أفراد عينة البحث لعبارات هحور قياس الأداء جدول (10)

التكرار والنسبة المئوية وقيمة كا² وترتيب العبارات لاستجابات

\begin{tabular}{|c|c|c|c|c|c|c|c|c|c|}
\hline \multirow[b]{2}{*}{ الترتيب } & \multirow{2}{*}{ قالمسيوة كابة } & \multirow{2}{*}{ النسبى الوزن } & \multicolumn{2}{|l|}{$\gamma$} & \multicolumn{2}{|c|}{ الى حد ما } & \multicolumn{2}{|c|}{ نعم } & \multirow{2}{*}{ المبحرات } \\
\hline & & & نسبة \% & تكرار & نسبة \% & تكرار & نسبة \% & تكرار & \\
\hline 17 & ${ }^{* 33.49}$ & 247 & $\overline{c 6.73}$ & 7 & 49.04 & $\overline{51}$ & 44.23 & 46 & 14 \\
\hline 16 & *36.0 & & 77 & & 50.00 & 52 & 4.23 & & 15 \\
\hline 8 & ${ }^{*} 40.76$ & 153 & 3.85 & 4 & 49.04 & 51 & 47.12 & 49 & 16 \\
\hline 2 & ${ }^{*} 52.24$ & 268 & 5.77 & 6 & 30.77 & 32 & 63.46 & 66 & 17 \\
\hline 13 & ${ }^{*} 41.62$ & 250 & 3.85 & 4 & 51.92 & 54 & 44.23 & 46 & 18 \\
\hline 8 & ${ }^{*} 40.76$ & 253 & 3.85 & 4 & 49.04 & 51 & 47.12 & 49 & 19 \\
\hline
\end{tabular}




\begin{tabular}{c|c|c|c|c|c|c|c|c|c}
\hline 10 & ${ }^{*} 52.29$ & 251 & 0.96 & 1 & 56.73 & 59 & 42.31 & 44 & $\mathbf{2 0}$ \\
\hline 14 & ${ }^{*} 49.86$ & 249 & 1.92 & 2 & 56.73 & 59 & 41.35 & 43 & $\mathbf{2 1}$ \\
\hline 18 & ${ }^{*} 45.37$ & 245 & 3.85 & 4 & 56.73 & 59 & 39.42 & 41 & $\mathbf{2 2}$ \\
\hline 1 & ${ }^{*} 33.25$ & 311 & 6.73 & 7 & 45.19 & 47 & 48.08 & 50 & $\mathbf{2 3}$ \\
\hline 6 & ${ }^{*} 35.80$ & 257 & 5.77 & 6 & 49.04 & 51 & 45.19 & 47 & $\mathbf{2 4}$ \\
\hline 218 & ${ }^{*} 45.37$ & 245 & 3.85 & 4 & 56.73 & 59 & 39.42 & 41 & $\mathbf{2 5}$ \\
\hline$م 10$ & ${ }^{*} 38.22$ & 251 & 4.81 & 5 & 49.04 & 51 & 46.15 & 48 & $\mathbf{2 6}$ \\
\hline 22 & ${ }^{*} 33.71$ & 237 & 8.65 & 9 & 54.81 & 57 & 36.54 & 38 & $\mathbf{2 7}$ \\
\hline 21 & ${ }^{*} 38.33$ & 240 & 6.73 & 7 & 55.77 & 58 & 37.50 & 39 & $\mathbf{2 8}$ \\
\hline 20 & ${ }^{*} 39.26$ & 243 & 5.77 & 6 & 54.81 & 57 & 39.42 & 41 & $\mathbf{2 9}$ \\
\hline 4 & ${ }^{*} 47.62$ & 262 & 1.92 & 2 & 44.23 & 46 & 53.85 & 56 & $\mathbf{3 0}$ \\
\hline 7 & ${ }^{*} 38.22$ & 254 & 4.81 & 5 & 46.15 & 48 & 49.04 & 51 & $\mathbf{3 1}$ \\
\hline 22 & ${ }^{*} 53.15$ & 268 & 1.92 & 2 & 38.46 & 40 & 59.62 & 62 & $\mathbf{3 2}$ \\
\hline 5 & ${ }^{*} 44.57$ & 260 & 2.88 & 3 & 44.23 & 46 & 52.88 & 55 & $\mathbf{3 3}$ \\
\hline 10 & ${ }^{*} 44.57$ & 251 & 2.88 & 3 & 52.88 & 55 & 44.23 & 46 & $\mathbf{3 4}$ \\
\hline 214 & ${ }^{*} 45.83$ & 249 & 2.88 & 3 & 54.81 & 57 & 42.31 & 44 & $\mathbf{3 5}$ \\
\hline \hline
\end{tabular}

قيمة كا2 2.99 عند (2 ، 20.05

يتضـح من جدول (10) أن قيمـة كـا2 المحسوبة لاستجابات افراد عينة البحث لعبارات

محور قياس الاداء جميعها دالة إحصائيا عند مستوى معنوية 0.05 .

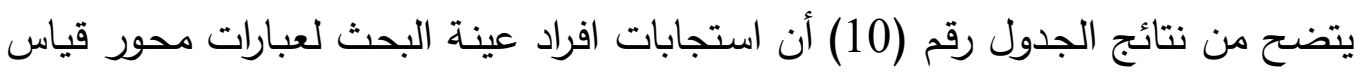
الاداء قد تراوح التكرار للإجابة ( نعم ) ما بين (38 ، 66) وبنسبة مئوية تتراوح ما بين (36.54\% ، 63.46\%), ويتراوح التكرار للإجابة (إلى حد ما) مـا بين (32 ، 59) وبنسبة مئوية تتراوح ما بين (30.77\%، 56.73\%) , ويتراوح التكرار للإجابة ( لا ) ما بين (1 ، 9) وبنسبة مئوية تتراوح ما بين (0.96\% ، 8.65\%), وأن قيمة كا² المحسوبة تتراوح ما بين (33.25 , 53.15) ، وهى فروق ذات دلالة إحصائية فى الاستجابة لجميع عبارات المحور، حيث جاءت قيمة كا² المحسوبة أكبر من قيمة كا² الجدولية عند مستوى معنوية (0.05) ، وكانت أعلى الدرجات تكراراً للإجابة ( نعم ) هى ان قياس الاداء بالأندية الرياضية بدولة الكويت يشجع العاملين على تحسين ادائهم ، وان الجمعية العمومية تقوم بتقييم سياسات مجلس الادارة للأندية الرياضية بدولة الكويت ، وان قياس الاداء للعـاملين مـن قبل رئيسهـم الادارى المباشـر يؤدى الـى الارتقاء بمستوى الانجـاز ، والتقارير المرفوعة من مجلس ادارة الأندية الرياضية بدولة الكويت للجمعية العمومية تسهم فى ازالة معوقات العملية الرقابية، وان اساليب تقويم الاداء الرقابى تسهم فى تطوير مستوى الأندية الرياضية بدولة الكويت ، وان اللجنة الاوليمبية تقوم بقياس اداء الأندية الرياضية بدولة الكويت. 
ويعزى الباحث ذلك الى ان الادارة بالأندية الرياضية تقوم بقياس الاداء الفعلى لمعرفة ما ينجز فيها ومقارنته بالمعيار الرقابى لمعرفة مدى مقدار الانحراف عنه، وان سلامة الاداء تتوقف على مقدار الدقة فى قياس الاعمال المنجزة ، فمن الناحية العلمية هناك استحالة ان نقوم بقياس كل انشطة الهيئة الرياضية، والا كانت تكاليف الرقابة اكبر بكثير من الفوائد التى تعود على الهيئة

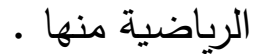

لابد من عقد مقارنة بين النتائج المحققة وبين المعايير والانماط المحدة للاداء، وان يخبر

بنتيجة المقارنة كل من يستطيع اتخاذ قرار او اجراء بثانها، والا فقدت الرقابة مبررها واسبابها .

وهذا يجيب عن التساؤل القائل " ما واقع الأداء الرقابى بالأندية الرياضية بدولية الكويت

وذلك من خلال قياس الاداء بالأندية الرياضية بدولة الكويت ؟ " .

3- عرض نتائج استجابات افراد عينة البحث لهبارات همور تشخيص المشكلات

جدول (11)

التكرار والنسبة المئوية وقيمة كا2 وترتيب العبارات لاستجابات افراد

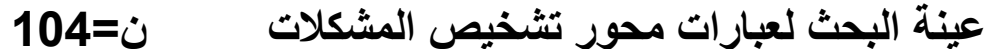

\begin{tabular}{|c|c|c|c|c|c|c|c|c|c|}
\hline \multirow[b]{2}{*}{ الترتيب } & \multirow{2}{*}{ المحسوبة } & \multirow{2}{*}{ النسبى } & \multicolumn{2}{|l|}{ ل } & \multicolumn{2}{|c|}{ الى حـ ما } & \multicolumn{2}{|c|}{ نعم } & \multirow{2}{*}{ عبارات } \\
\hline & & & نسبة ٪ & تكرار & نسبة \% & تكرار & نسبة ٪ & تكرار & \\
\hline 12 & *33.71 & $\overline{237}$ & 8.65 & 9 & 54.81 & 57 & 36.54 & 38 & 36 \\
\hline 10 & ${ }^{*} 43.29$ & 243 & 4.81 & 5 & 56.73 & 59 & 38.46 & 40 & 37 \\
\hline 3 & ${ }^{*} 45.83$ & 249 & 2.88 & 3 & 54.81 & 57 & 42.31 & 44 & 38 \\
\hline 4 & ${ }^{*} 46.64$ & 248 & 2.88 & 3 & 55.77 & 58 & 41.35 & 43 & 39 \\
\hline 8 & ${ }^{*} 45.37$ & 245 & 3.85 & 4 & 56.73 & 59 & 39.42 & 41 & 40 \\
\hline 6 & ${ }^{*} 43.52$ & 247 & 3.85 & 4 & 54.81 & 57 & 41.35 & 43 & 41 \\
\hline 13 & ${ }^{*} 46.79$ & 235 & 6.73 & 7 & 60.58 & 63 & 32.69 & 34 & 42 \\
\hline 4 & ${ }^{*} 42.77$ & 248 & 3.85 & 4 & 53.85 & 56 & 42.31 & 44 & 43 \\
\hline 11 & ${ }^{*} 48.60$ & 239 & 4.81 & 5 & 60.58 & 63 & 34.62 & 36 & 44 \\
\hline 66 & ${ }^{*} 43.52$ & 247 & 3.85 & 4 & 54.81 & 57 & 41.35 & 43 & 45 \\
\hline 13 & ${ }^{*} 13.51$ & 235 & 16.35 & 17 & 41.35 & 43 & 42.31 & 44 & 46 \\
\hline 1 & ${ }^{*} 53.67$ & 269 & 3.85 & 4 & 33.65 & 35 & 62.50 & 65 & 47 \\
\hline 9 & ${ }^{*} 34.86$ & 244 & 6.73 & 7 & 51.92 & 54 & 41.35 & 43 & 48 \\
\hline 2 & ${ }^{*} 38.10$ & 253 & 4.81 & 5 & 47.12 & 49 & 48.08 & 50 & 49 \\
\hline
\end{tabular}

قيمة كا 2 عند ( 2 ، $0.99=05$

يتضـح من جدول (11) أن قيمـة كـا2 المحسوبة لاستجابات افراد عينـة البحث لعبارات

محور تثخيص المشكلات جميعها دالة إحصائيا عند مستوى معنوية 0.05 . 
يتضـح مـن نتـائج الجدول رقم (11) أن استجابات افراد عينـة البحـث لعبـارات محسور تثخيص المشكلات قد تراوح التكرار للإجابة ( نعم ) ما بين (34 ، 65) وبنسبة مئوية تتراوح ما بين (32.69\% ، 62.50\%), ويتراوح التكرار للإجابة (إلى حد ما) مـا بين (35 ، 63) وبنسبة

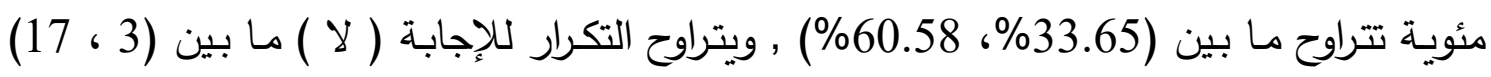
وبنسبة مئويـة تتراوح مـا بين (2.88\% ، 16.35\%), وأن قيمـة كـا2 المحسوبة تتـراوح مـا بين (13.51 , 53.67) ، وهى فروق ذات دلالة إحصائية فى الاستجابة لجميع عبارات المحور ، حيث

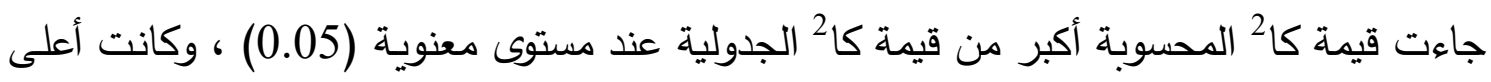
الدرجات تكراراً للإجابة ( نعم ) هى ضعف الدور الرقابى للادارة بالأندية الرياضية بدولة الكويت

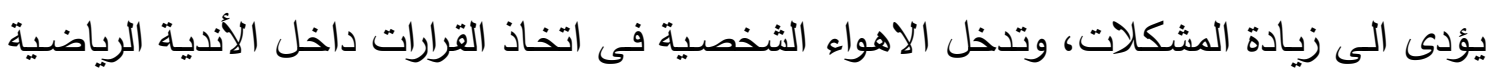
بدولة الكويت يؤثر سلبا على سير العملية الرقابية ، وان هناك ازدواجية فى تطبيق العملية الرقابية من قبل اعضاء الجمعية العمومية واعضاء الجهة الادارية الدختصة مما يؤدى الى فقدان الثقة . ويعزى الباحث ذلك الى ان اهم المشكلات التى تواجه الرقابة داخل الهيئات الرياضية هى عدم التزام مجالس الادارات بتطبيق اللوائح والقوانين المنظمـة للعمل ممـا يؤدى الى تكرار ورود الملاحظات من الجهة الحكومية ، كما ان تصيد الاخطاء وعدم تصحيحها نتيجة لبعض الاهواء الذاتية يؤدى الى تفاقم المشكلات . إن وظيفة الرقابة تتضمن اوجه النشاط التى تعمل على ان تتمشى الحوادث والتصرفات مع الخطط المرسومة ، ومعنى ذلك ان يتعرف المدير على الانحرافات المختلفة عن الخطط المرسومة وان يحدد الاشخاص المسئولين عن حدوث هذه الانحرافات عن معايير العمل وان يتخذ اللازم نحو

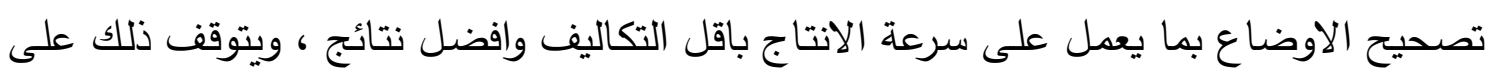
سرعة وكفاية البيانات التى تصل الى المدير حتى يتمكن من معالجة الموقف وتصحيح الاخطاء فى الوقت المناسب ـ (4 : وتتقق تلك النتائج مع دراسة ثروت محمد عبد الله ابو السبح 2005م (3) فى عدم معرفة الاعضاء باللوائح والقوانين التى تنظم العمل داخل الهيئة. وهذا يجيب عن التساؤل القائل " ما واقع الأداء الرقابى بالأندية الرياضية بدولة الكويت وذلك من خلال تصحيح الانحراف بالأندية الرياضية بدولة الكويت ؟ " . 


\section{4- عرض نتائج استجابات افراد عينة البحث لعبارات هحور تصحيح الانشراف}

جدول (12)

التكرار والنسبة المئوية وقيمة كا2 وترتيب العبارات لاستجابات افراد

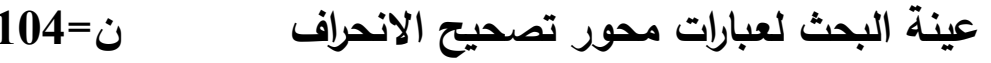

\begin{tabular}{|c|c|c|c|c|c|c|c|c|c|}
\hline \multirow{2}{*}{ الترتيب } & \multirow{2}{*}{ قالمحسوبة } & \multirow{2}{*}{ النسبى } & \multicolumn{2}{|c|}{ ע } & \multicolumn{2}{|c|}{ الى حد ما } & \multicolumn{2}{|c|}{ نعم } & \multirow{2}{*}{ مبلدرات } \\
\hline & & & نسبة ٪ & تكرار & نسبة \% & تكرار & نسبة \% & تكرار & \\
\hline 3 & *48.25 & 251 & 1.92 & 2 & 54.81 & 57 & 43.27 & 45 & 50 \\
\hline 6 & ${ }^{*} 50.84$ & 248 & 1.92 & 2 & 57.69 & 60 & 40.38 & 42 & 51 \\
\hline ק3 & ${ }^{*} 44.57$ & 251 & 2.88 & 3 & 52.88 & 55 & 44.23 & 46 & 52 \\
\hline 10 & *57.48 & 243 & 1.92 & 2 & 62.50 & 65 & 35.58 & 37 & 53 \\
\hline 33 & ${ }^{*} 48.25$ & 251 & 1.92 & 2 & 54.81 & 57 & 43.27 & 45 & 54 \\
\hline 2 & ${ }^{*} 44.10$ & 252 & 2.88 & 3 & 51.92 & 54 & 45.19 & 47 & 55 \\
\hline 1 & ${ }^{*} 43.41$ & 255 & 2.88 & 3 & 49.04 & 51 & 48.08 & 50 & 56 \\
\hline 7 & ${ }^{*} 43.52$ & 247 & 3.85 & 4 & 54.81 & 57 & 41.35 & 43 & 57 \\
\hline 8 & *43.76 & 245 & 2.88 & 3 & 50.96 & 53 & 46.15 & 48 & 58 \\
\hline 13 & ${ }^{*} 34.87$ & 236 & 8.65 & 9 & 55.77 & 58 & 35.58 & 37 & 59 \\
\hline 88 & ${ }^{*} 37.64$ & 245 & 5.77 & 6 & 52.88 & 55 & 41.35 & 43 & 60 \\
\hline 11 & ${ }^{*} 40.24$ & 242 & 5.77 & 6 & 55.77 & 58 & 38.46 & 40 & 61 \\
\hline 12 & *38.33 & 240 & 6.73 & 7 & 55.77 & 58 & 37.50 & 39 & 62 \\
\hline 14 & ${ }^{*} 17.91$ & 229 & 15.38 & 16 & 49.04 & 51 & 35.58 & 37 & 63 \\
\hline
\end{tabular}

قيمة كا 2.99 عند ( 2 ، 0.05

يتضـح من جدول (12) أن قيمـة كـا2 المحسوبة لاستجابات افراد عينـة البحث لعبارات

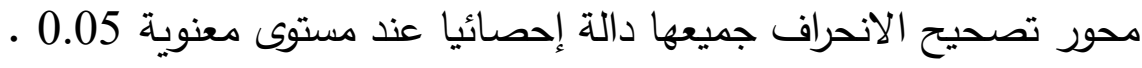

يتضح من نتائج الجدول رقم (12) أن استجابات افراد عينة البحث لعبارات محور تصحيح

الانحراف قد تـراوح التكرار للإجابـة ( نعم ) مـا بين (37 ، 50) وبنسبة مئويـة تتراوح مـا بين

(35.58\% ، 48.08\%), ويتراوح التكرار للإجابة (إلى حد ما) ما بين (51 ، 65) وبنسبة مئوية

تتراوح ما بين (49.04\%، 62.50\%) , ويتراوح التكرار للإجابة ( لا ) ما بين (2 ، 16) وبنسبة

مئويسة تتراوح ما بين (1.92\% ، 15.38\%) , وأن قيمة كا2 المحسوبة تتراوح ما بين (17.91 ,

57.48) ، وهى فروق ذات دلالة إحصائية فى الاستجابة لجميع عبارات الدحور، حيث جاءت

قيمة كا² المحسوبة أكبر من قيمة كا² الجدولية عند مستوى معنوية (0.05) .

ويعزى الباحث ذلك الى ان اساليب الرقابة تستخدم عدة اشكال ، فالبعض منها يبحث فى ملى

صحة الموقف المالى ، والبعض الاخر يهتم بكفاءة العاملين فى تنفيذ الاعمال واساليب اخرى 
تتعامل مـع اتجاهـات وادراك العاملين فى حين يركز البعض الاخر على قياس الاداء الكلى ، وبالرغم من اختلاف ادوات الرقابة الا انها جميعا تبحث فى هدف واحد وهو تحديد الانحرافات

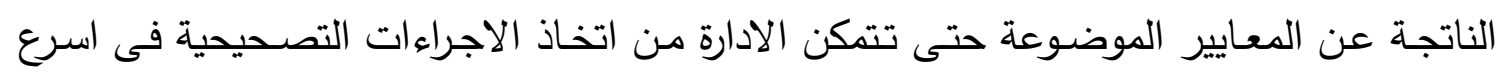
وقت مدكن قبل ان تتفاقم الانحرافات وتكون الخسائر فادحة . إن كل ادارى يقوم بعملية الرقابة فى حدود الخطط التى وضعها ، ومهمة عضو الرقابة

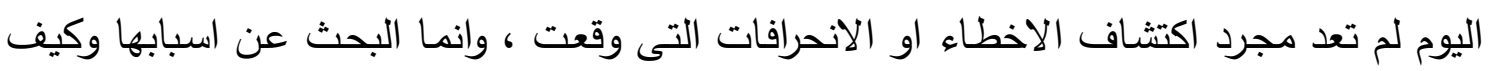
يمكن تجنب وقوعها فى المستقبل ، وتوجيه القائمين على العمل الى طرق افضل لاداء الاعمال . (8 : 28) ، وما اشار اليه حليم المنيرى ، عصام بدوى 1991م ان الغرض الاساسى فى عملية الرقابة ليس اكتشاف المخالفات فى حد ذاتها ، ولكن المهم هو رسم الطريق للاصـلاح والتوجيه ويكون ذلك عن طريق تقدير المسئولية وبيان كيفيه تصحيح الاخطاء ـ (4 : 88) وتتقق هذه النتيجة مع ما أشار اليه إبراهيم كرم وعبد الحميد مطر 1990م أنه يجب على النظام الرقابى أن يبلغ عن الانحرافات بسرعة وفى الوقت المناسب، وعدم تصيد الأخطاء والاتجاه إلى الإصلاح ومعالجة المشاكل (1 : 78) • وتتقق تلك النتائج مع دراسة ثروت محمد عبد الله ابو السبح 2005م (3) فى ان الرقابة لاتهدف الى تصحيح الاخطاء وانما تهدف الى تصيدها ، وعدم استخدام اسلوب التفتيش المفاجىء بصورة مستمرة.

وهذا يجيب عن التساؤل القائل " ما واقع الأداء الرقابى بالأندية الرياضية بدولة الكويت وذلك من خلال تثخيص المشكلات بالأندية الرياضية بدولة الكويت ؟ " .

5- عرض نتائج استجابات افراد عينة البحث لعبارات هصور اهداف العملية الرقابية

جذول (13)

التكرار والنسبة المئوية وقيمة كا² وترتيب العبارات لاستجابات افراد عينة البحث لعبارات محور اهداف العملية الرقابية ن

\begin{tabular}{|c|c|c|c|c|c|c|c|c|c|}
\hline \multirow{2}{*}{ الترتيب } & \multirow{2}{*}{ قالمسبوبة كا2 } & \multirow{2}{*}{ النسبى } & \multicolumn{2}{|c|}{$\gamma$} & \multicolumn{2}{|c|}{ الى حد ما } & \multicolumn{2}{|c|}{ نعم } & \multirow{2}{*}{ المحارات } \\
\hline & & & نسبة ٪ & تكرار & نسبة \% & تكرار & نسبة \% & تكرار & \\
\hline 13 & ${ }^{*} 49.86$ & 249 & 1.92 & 2 & 56.73 & 59 & 41.35 & 43 & 64 \\
\hline
\end{tabular}




\begin{tabular}{c|c|c|c|c|c|c|c|c|c}
\hline 4 & ${ }^{*} 50.22$ & 263 & 0.96 & 1 & 45.19 & 47 & 53.85 & 56 & $\mathbf{6 5}$ \\
\hline 2 & ${ }^{*} 48.60$ & 265 & 2.88 & 3 & 39.42 & 41 & 57.69 & 60 & $\mathbf{6 6}$ \\
\hline 1 & ${ }^{*} 57.48$ & 271 & 1.92 & 2 & 35.58 & 37 & 62.50 & 65 & $\mathbf{6 7}$ \\
\hline 5 & ${ }^{*} 45.83$ & 262 & 2.88 & 3 & 42.31 & 44 & 54.81 & 57 & $\mathbf{6 8}$ \\
\hline 17 & ${ }^{*} 44.39$ & 246 & 3.85 & 4 & 55.77 & 58 & 40.38 & 42 & $\mathbf{6 9}$ \\
\hline 6 & ${ }^{*} 49.07$ & 259 & 0.96 & 1 & 49.04 & 51 & 50.00 & 52 & $\mathbf{7 0}$ \\
\hline 14 & ${ }^{*} 55.41$ & 248 & 0.96 & 1 & 59.62 & 62 & 39.42 & 41 & $\mathbf{7 1}$ \\
\hline 18 & ${ }^{*} 59.15$ & 242 & 1.92 & 2 & 63.46 & 66 & 34.62 & 36 & $\mathbf{7 2}$ \\
\hline 19 & ${ }^{*} 53.67$ & 239 & 3.85 & 4 & 62.50 & 65 & 33.65 & 35 & $\mathbf{7 3}$ \\
\hline 15 & ${ }^{*} 51.94$ & 247 & 1.92 & 2 & 58.65 & 61 & 39.42 & 41 & $\mathbf{7 4}$ \\
\hline 12 & ${ }^{*} 44.57$ & 251 & 2.88 & 3 & 52.88 & 55 & 44.23 & 46 & $\mathbf{7 5}$ \\
\hline 8 & ${ }^{*} 46.18$ & 257 & 1.92 & 2 & 49.04 & 51 & 49.04 & 51 & $\mathbf{7 6}$ \\
\hline 11 & ${ }^{*} 40.76$ & 253 & 3.85 & 4 & 49.04 & 51 & 47.12 & 49 & $\mathbf{7 7}$ \\
\hline 9 & ${ }^{*} 43.41$ & 256 & 2.88 & 3 & 48.08 & 50 & 49.04 & 51 & $\mathbf{7 8}$ \\
\hline 3 & ${ }^{*} 49.00$ & 264 & 1.92 & 2 & 42.31 & 44 & 55.77 & 58 & $\mathbf{7 9}$ \\
\hline 26 & ${ }^{*} 40.52$ & 259 & 4.81 & 5 & 41.35 & 43 & 53.85 & 56 & $\mathbf{8 0}$ \\
\hline 29 & ${ }^{*} 37.00$ & 256 & 5.77 & 6 & 42.31 & 44 & 51.92 & 54 & $\mathbf{8 1}$ \\
\hline 15 & ${ }^{*} 23.68$ & 247 & 11.54 & 12 & 39.42 & 41 & 49.04 & 51 & $\mathbf{8 2}$ \\
\hline \hline
\end{tabular}

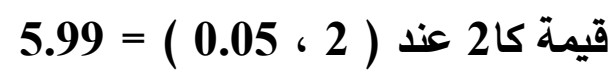

يتضـح مـن جدول (13) أن قيمـة كـا2 المحسوبة لاستجابات افراد عينـة البحث لعبـارات

محور اهداف العملية الرقابية جميعها دالة إحصائيا عند مستوى معنوية 0.05 ـ يتضح من نتائج الجدول رقم (13) أن استجابات افراد عينة البحث لعبارات محور اهداف

العملية الرقابية قد تراوح التكرار للإجابة ( نعم ) ما بين (35 ، 65) وبنسبة مئويـة تتراوح ما بين (633.65\% ، 62.50\%), ويتراوح التكرار للإجابة (إلى حد ما) ما بين (37 ، 66) وبنسبة مئويـة تتراوح ما بين (55.58\%، 63.46\%) , ويتراوح التكرار للإجابة ( لا ) ما بين (1 ، 12) وبنسبة مئويـة تتراوح مـا بين (0.96\% ، 11.54\%), وأن قيمـة كـ2 المحسوبة تتراوح مـا بين (23.68 , 59.15) ، وهى فروق ذات دلالمة إحصـائية فى الاستجابة لجميع عبارات المحور ، حيث جاءت قيمـة كـا2 المحسـوبة أكبر مـن قيمـة كـا2 الجدوليـة عند مسـتوى معنويـة (0.05) ، وكانـت أعلى الدرجات تكراراً للإجابة ( نعم ) هى ان الرقابة تبدا بالأندية الرياضية بدولة الكويت مع بداية التنفيذ الفعلى للعمليات الادارية ، وتتعاون اللجنة الاوليمبية فى تحديد أهداف الرقابة بالأندية الرياضية بدولة الكويت ، وان الرقابة داخل الأندية الرياضية بدولة الكويت تسـاعد فى التعرف على مدى التقدم فـى الاداء ، وان الهيئة العامـة للشباب والرياضـة تتعاون فى تحديد أهداف الرقابـة بالأنديـة الرياضـية بدولـة الكويـت ، وان الرقابـة على مسـتوى اداء العـاملين تهدف الـى النهوض بالأنديـة 
الرياضية بدولة الكويت ، والتاكد من قانونية انفاق الموارد المالية للأندية الرياضية بدولة الكويت يعد من المهام الاساسية للرقابة ، كما تساعد الرقابة على التاكد من ان الاعمال الاداريـة تؤدى

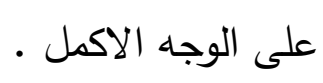
ويعزى الباحث ذلك الى ان الرقابة عملية مستمرة ابتداء من التخطيط حتى عملية التتفيذ وانجاز الاعمال ، وبالتالى تئودى الى ان الفرد يقوم باداء العمل المطلوب منـه ، كمـا ان الرقابة

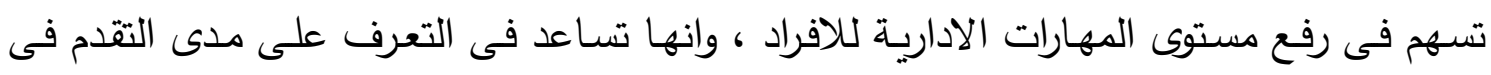
الاداء وان الرقابة على مستوى الافراد ضرورة للنهوض بالهيئات الرياضية . إن مجلس ادارة الهيئة الرياضية لا يمكن ان يكون بعيدا عن التنفيذ ، وليس مهمته ان يتخذ القرارات فقط ، ولكن يدخل فى صميم اختصاصاته متابعة تتفيذ القرارات التى يتخذها ويتاكد

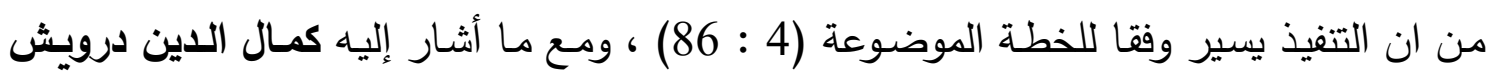
وأخرون 1993م على أن الرقابة تمر بثلاث مراحل وهى - تحديد المعايير أو المقاييس الرقابية -

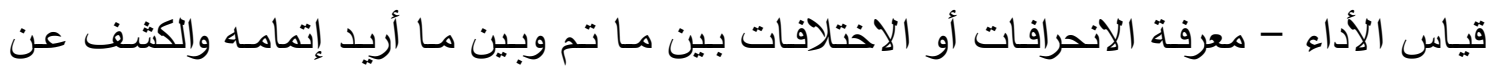
أسباب تلك الانحرافات والعمل على تصحيحها (10 : 67). وتختلف تلك النتائج هـع دراسـة ثروت محمد عبد الله ابـو السبح 2005م (3) فى ان الرقابة لاتهدف الى تصحيح الاخطاء وانما تهدف الى تصيدها ، وعدم استخدام اسلوب التفتيش المفاجىء بصورة مستمرة.

وهذا يجيب عن التساؤل القائل " ما واقع الأداء الرقابى بالأندية الرياضية بدولة الكويت وذلك من خلال أهداف الرقابة الادارية على الأندية الرياضية بدولة الكويت ؟ " . .

الإستخلاصات والتوصيات اولا : الإستخلاصات

فى ضوء النتائج التى تم التوصل اليها وفى حدود عينة الدراسة ، وادوات جمع البيانات المستخدمة وفى ضوء اهداف البحث ومن خلال المراجعة التى قام بها الباحث للدراسات والبحوث التى أجريت فى هذا المجال ، يعرض الباحث فيما يلى اهم الإستخلاصـات التى خلصت اليها الدراسة: توجد معايير رقابية بالأندية الرياضية بدولة الكويت. 
قياس الاداء بالأندية الرياضية بدولة الكويت يشجع العاملين على تحسين ادائهم. • اهداف الأندية الرياضية بدولة الكويت واضحة بدرجة كافية تمكننا من قياس مستوى الاداء ،

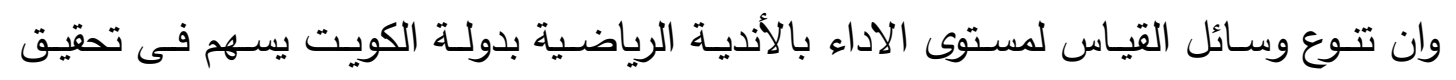

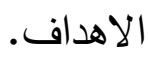
قـاس الاداء بالأنديـة الرياضية بدولـة الكويت احــ الوسـائل الهامـة للتعرف على نقاط القوة

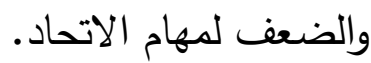

فاعلية الرقابة على الانثطة داخل النادى لاتعتمد بصورة اساسية على الجمعية العمومية . ضعف الدور الرقابى للادارة بالأندية الرياضية بدولة الكويت يؤدى الى زيادة المشكلات.

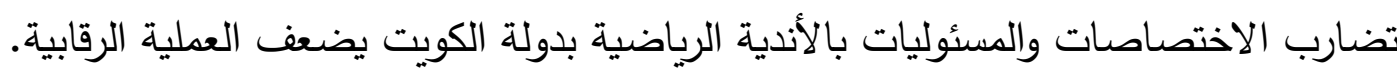
الرقابة الفورية المفاجئة احد اهم اساليب الرقابة داخل الأندية الرياضية بدولة الكويت لتصحيح

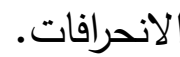

ه دقة تتفيذ العملية الرقابية بالأندية الرياضية بدولة الكويت يؤدى للحصول على تقارير واقعية. هالرقابة تبدأ بالأندية الرياضية بدولة الكويت مع بداية التتفيذ الفعلى للعمليات الادارية. تساعد الرقابة بالأندية الرياضية بدولة الكويت على تنفيذ الخطط باقل الامكانات. تهدف العملية الرقابية الى التاكد من ان الاعمال تسير فى اتجاه تحقيق الاهداف المحددة، وان تكثف الرقابة عن المعوقات التى تعترض سير العمل داخل الأندية الرياضية بدولة الكويت. ثانيا : التوصيات في ضوء نتائج البحث والإستخلاصات التي تم التوصل إليها يوصي الباحث بما يلي:

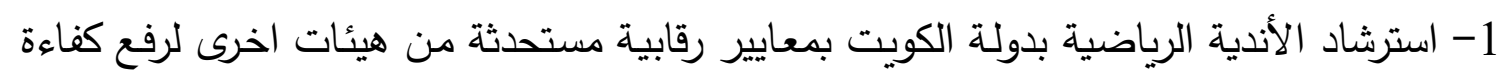

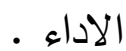

2- تقديم تقرير لكل مسئول بالأندية الرياضية بدولة الكويت بمستوى ادائه . 3- الاعتمـاد بصـورة اساسية على الجمعيـة العموميـة لزيـادة فاعلية الرقابة على الانشطة داخل · النادى 4- تفعيل الدور الرقابى للجمعية العمومية على مجلس ادارة الأندية الرياضية بدولة الكويت. 
5- إجراء بحـوث مستقبلية تعهل على وضـع حلول لمعالجـة السلبيات التى ظهرت من خـلال

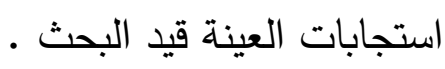

6- مراعـاة زيـادة الاهتمـام بأسـاليب الاتصـال لتوفير المعلومـات لـى اعضـاء الجمعيـة العموميـة بالأندية الرياضية بدولة الكويت.

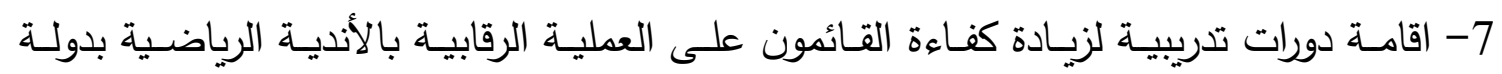

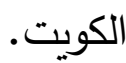
8- تحديد الوصف الوظيفى للعاملين بالأندية الرياضية بدولة الكويت بشكل لا يحدث تضارب فى الاختصاصات والمسئوليات لتقوية العملية الرقابية .

9- عقد ورش عمل لتوضيح السياسات اللوائح المنظمة للعمل بالأندية الرياضية بدولة الكويت. 10- عقد اللقاءات الدوريـة لاعضـاء الجمعية العمومية مـع مجالس ادارة الأنديـة الرياضية بدولـة الكويت لمناقشة امور تتعلق باتخاذ القرار فيها .

قائمة المراجع أولا: المراجع العربية

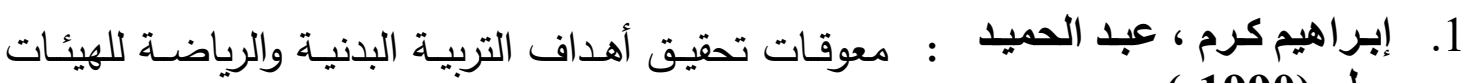

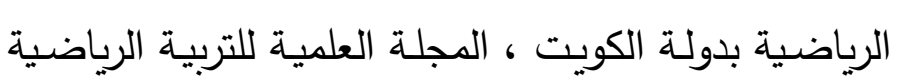
مطر (1990م)

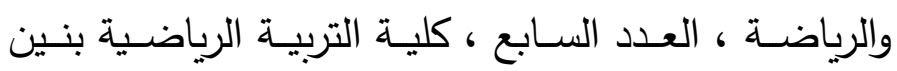
بالقاهرة، جامعة حلوان.

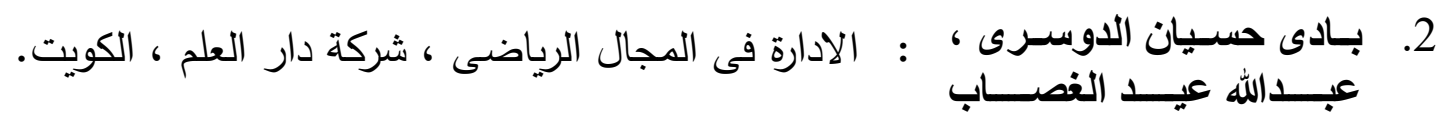
(2007)

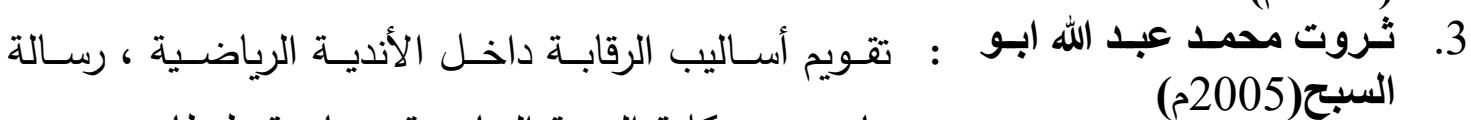
ماجستير ، كلية التربية الرياضية , جامعة طنطا.

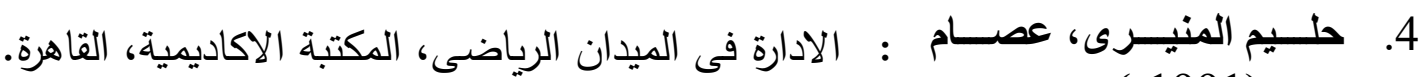

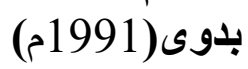

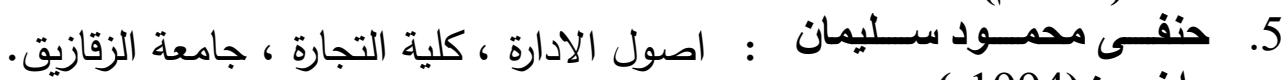

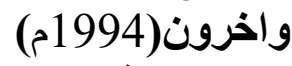

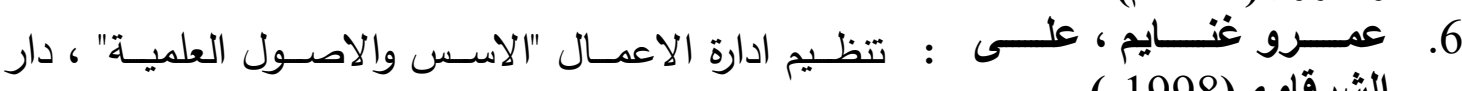
النهضة للطباعة والنشر ، القاهرة .

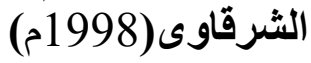

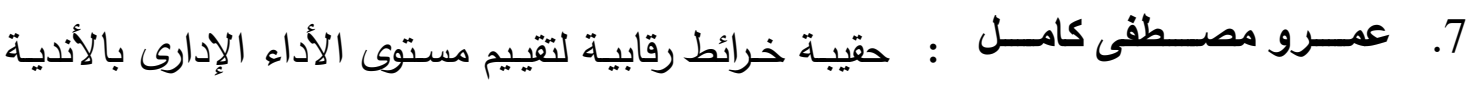


الرياضية المصرية ، المجلة العلمية ، كلية التربية الرياضية

$$
\text { ، جامعة أسيوط . }
$$

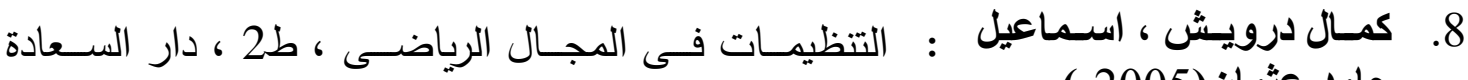
للطباعة ، القاهرة .

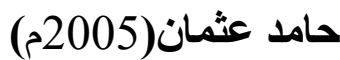
9. كمــال درويسش، أثــرف المنظمات الرياضية الأهلية، مكتبة الأصدقاء، القاهرة.

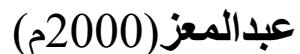
ر : الإدارة الرياضية " الأسس ، التطبيقات " ، الهيئة المصرية

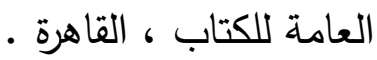

: : تطبيقات الإدارة الرياضية ، مركز الكتاب للنشر ، القاهرة .

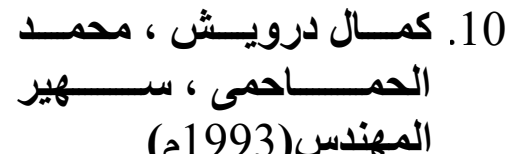

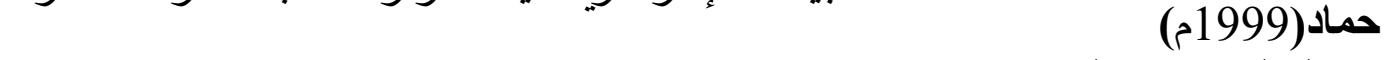
12. نبيـل الحسـيني النجــار ، الإدارة المتقدمـة " أفضـل الممارسـات " ، المكتبة العصـرية

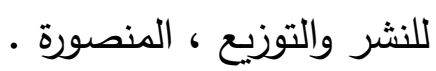

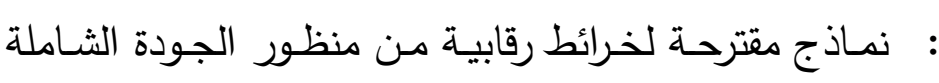
ببعض الإتحادات الرياضية، رسالة دكتوراه منشورة، كلية

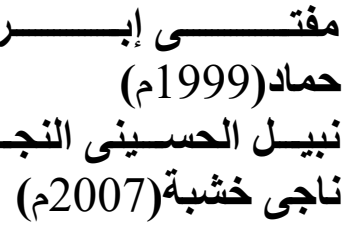
11

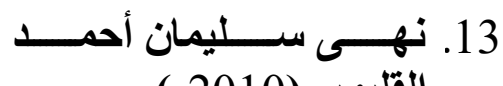
القليوبى(2010م)

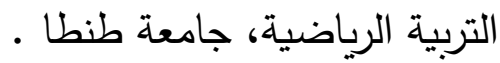

\section{ثانيا : المراجع الأجنبية}

14. Hart Gordon MR . Strategies and methods of effective (1994) supervision, ERIC, digest. 